Original Contribution

\title{
EFFECT OF SUBLETHAL CONCENTRATION OF BEAUVERIA BASSIANA FUNGUS ON DEMOGRAPHIC AND SOME BIOCHEMICAL PARAMETERS OF PREDATORY BUG, ANDRALLUS SPINIDENS FABRICIUS (HEMIPTERA: PENTATOMIDAE) IN LABORATORY CONDITIONS
}

\author{
M. Gholamzadeh-Chitgar ${ }^{1,2^{*}}$, J. Hajizadeh ${ }^{2}$, M. Ghadamyari ${ }^{2}$, A. Karimi-Malati ${ }^{2}$ \\ H. Hoda ${ }^{3}$
}

${ }^{1}$ Plant Protection Research Department, Mazandaran Agricultural and Natural Resources Research and Education Center, Agricultural Research, Education and Extension Organization (AREEO), Sari, Iran

${ }^{2}$ Department of Plant Protection, Faculty of Agricultural Science, University of Guilan, Rasht, Iran

${ }^{3}$ Iranian Research Institute of Plant Protection, Agricultural Research, Education and Extension

Organization (AREEO), Tehran, Iran

\begin{abstract}
Effects of Beauveria bassiana on Andrallus spinidens Fabricius (Hemiptera: Pentatomidae), a predator of lepidopterous larvae in rice fields were investigated. The experiments were conducted at a concentration of $3 \times 10^{5}$ conidia $\mathrm{ml}^{-1}\left(\mathrm{LC}_{30}\right)$ of $B$. bassiana on life table and some biochemical parameters of fifth instar nymphs. Insects were infected by dipping in the conidial suspension for $10 \mathrm{~s}$. The results showed that pre-oviposition period, fecundity, percent egg hatchability and longevity of treated bugs were not significantly affected compared with the control. Esterase (using $\beta$-naphtil as substerate) and glutathione S-transferase activity in A. spinidens increased $48 \mathrm{~h}$ after treatment. The fungus did not cause adverse effect on acetylcholinesterase activity. B. bassiana did not cause significant difference on life table parameters of $A$. spinidens compared to the control. According to the present study, it can be concluded that B. bassiana is compatible with the predatory bug at sublethal concentration $\left(\mathrm{LC}_{30}\right)$.
\end{abstract}

Key Words: Andrallus spinidens, fungus, suspension, sublethal, life table, biochemical parameters

\section{INTRODUCTION}

Beauveria bassiana (Balsamo) Vuillemin (Hypocreales: Cordycipitaceae) is a well known entomopathogenic fungus that has great potential as biological control agent against a wide range of insects. Entomopathogenic fungi are one important component within integrated pest management systems. As a result of the excessive use of insecticides and the associated problems of them, there is an increasing demand for sustainable, environmentally friendly control methods. The success of fungal entomopathogens as biological control agents in the field depends not only on high efficacy against insect pests, but also on low virulence against non target insects (1).

Andrallus spinidens Fabricius is a non-specific predator of lepidopterous larvae in rice fields (2). Second to fifth instar nymphs and adults of

\footnotetext{
*Correspondence to: Moloud GholamzadehChitgar, Fax: 011-54262418; Email:

b_gh.chitgar60@yahoo.com
}

A. spinidens have predatory activity on larvae of rice pests such as: Chilo suppressalis Walker (Pyralidae), Naranga aenescens Moore (Noctuidae) and Mythimna unipunctata Haworth (Noctuidae) $(3,4)$. This pentatomid bug is distributed worldwide (5) and recognized as a potential biological control agent in rice fields in India, Malaysia and Iran $(2,3,6)$. There are three factors which favor $A$. spinidens as potentially useful biological control agent of rice pests: relatively short life cycle, aggressive feeding behavior and ability to feed continually for several hours (2). This natural enemy would be directly exposed to the B. bassiana in the field when this fungus was used as a biopesticide.

Many reports have described the detrimental effects of entomopathogenic fungi on insects (7, 8, 9). Majidishilsar, (10) reported that $B$. bassiana has great potential as biological agent for control of $C$. suppressalis. Therefore, $A$. spinidens would be exposed to field-applied entomopathogenic fungi if $B$. bassiana are 
used as a microbial control of $C$. suppressalis. If the fungus has negative effect on A.spinidens, predation of lepidopteran pests by the predatory bug may be limited in rice fields. Research has recently focused on the epizootiology and resultant effects of entomopathogenic fungi on predatory arthropods (1, 9, 11, 12, 13). Lethal and sublethal effects of entomopathogens on beneficial insects with regard to fecundity, longevity and survivorship are worth evaluating (13). Life table study is the best approach to combine the lethal and sublethal effects (14).

Xenobiotics can affect biochemical activity of detoxification enzymes in the exposed insects. In insects, general esterases (EST) and glutathione S-transferase (GST) are detoxifying enzymes to react against xenobiotics. Acetylcholinesterase (AChE) is a key enzyme that terminates nerve impulses by catalyzing the hydrolysis of the neurotransmitter acetylcholine in the nervous system. Glutathione S-transferase (E.C.2.5.1.18) belongs to the class of phase II detoxifying enzymes that catalyze the conjugation of glutathione with xenobiotics. The changes in the activity or spectrum of detoxification enzymes can induce infections in insects (15). Biochemical parameters seem quite promising to assess and predict the effects of toxicants on beneficial species (16). There is a relationship between toxicantinduced biochemical alternations and subsequent demographic changes as a pressing problem in Ecotoxicology (17).

There is no data about the effect of $B$. bassiana on the life table parameters of A. spinidens. The goal of current research was to assess the sublethal effects of $B$. bassiana on the life table and some biochemical parameters of $A$. spinidens to predict the potential of the pathogen in combination with $A$. spinidens for the control of rice pests.

\section{MATERIALS AND METHODS}

\section{Insect rearing}

The adults and nymphs of $A$. spinidens were collected from rice fields in Amol city, Mazandaran province (north of Iran $36^{\circ} 28^{\prime} 11^{\prime \prime} \mathrm{N} 52^{\circ} 21^{\prime} 03^{\prime \prime} \mathrm{E}$ ), in late September 2012. The predators were reared on last larval instars of Galleria mellonella L. (Lep.: Pyralidae) in laboratory condition $\left(25 \pm 2{ }^{\circ} \mathrm{C}\right.$, $60 \pm 10 \%$ RH (Relative humidity) and a photoperiod of 16:8 $\mathrm{h} \quad \mathrm{L}: \mathrm{D})$. The second generation of $A$. spinidens was used for the experiments.
GHOLAMZADEH-CHITGAR M., et al.

\section{Chemicals}

Acetylthiocholine iodide (ATC), 5, 5-dithiobis(2-nitrobenzoic acid, DTNB), triton X-100 were purchased from Sigma. Fast blue RR salt, $\alpha$-naphtyl acetate $(\alpha$-NA) and $\beta$-naphthyl acetate $(\beta-N A)$ were obtained from Fluka. 1chloro-2, 4-dinitrobenzene (CDNB) and acetone were purchased from Merck, Germany.

\section{Fungal culture and preparation of conidial suspension}

A strain of B. bassiana (IR-403) which was originally isolated from Chorthippus brunneus (Orthoptera: Acrididae) (supplied by Dr. M. Ghazavi, Plant Pests and Diseases Research Institute, Iran) was cultured on Sabouraud dextrose agar (SDA) at $25^{\circ} \mathrm{C}$ under continuous light. After 14 days, the conidia were removed from culture medium using a sterile spatula and suspended in $10 \mathrm{ml}$ sterile distilled water containing $0.05 \%$ Tween 80 . Suspensions were agitated for 5 minutes for homogenisation of the hydrophobic conidia. Then the suspension was passed through a two-folded mesh cloth to separate mycelium. In order to determine the number of spores, heamocytometer (Neubauer) was used. For bioassay, the suspensions were prepared at concentrations of $10^{4}, 10^{5}, 10^{6}, 10^{7}$ and $10^{8}$ conidia $\mathrm{ml}^{-1}$.

\section{Bioassays}

For bioassay, newly molted 5th-instar nymphs of A. spinidens immersed in conidial suspension of each concentration for 10 seconds and then excess suspension was removed using a filter paper. In the control, nymphs were treated with sterile distilled water containing $0.05 \%$ Tween- 80 . A total of 40 insects were used for each concentration and control. The treated insects were kept in a transparent plastic container $(\mathrm{d}=7 \mathrm{~cm}, \mathrm{~h}=10$ $\mathrm{cm})$. A $6 \mathrm{~cm}$ diameter hole was placed in the door of container for proper ventilation and covered with a mesh cloth. A piece of moistened cotton wool was placed in the bottom of each container to maintain the humidity. Then, these containers were kept in a chamber at $25 \pm 2{ }^{\circ} \mathrm{C}, 70 \pm 10 \%$ RH with a photoperiod of 16:8 hours (L: D) and were monitored daily for 8 days. The dead insects were counted and transferred to plastic Petri dishes $(90 \mathrm{~mm})$ covered with wet cotton wool in order to allow fungi to sporulate in dead insects. The $\mathrm{LC}_{30}$ of $B$. bassiana were determined.

\section{Life table parameters}

In order to study the sublethal effects of $B$. bassiana on the life table parameters of $A$. spinidens, 1- day- old fifth-instars nymphs of 
A. spinidens were used. The nymphs were treated with the $\mathrm{LC}_{30}$ of $B$. bassiana as mentioned above. The surviving nymphs were removed and kept in a transparent plastic container $(\mathrm{d}=7 \mathrm{~cm}, \mathrm{~h}=10 \mathrm{~cm})$. A $6 \mathrm{~cm}$ diameter hole was placed on the container lids for proper ventilation and covered with a mesh cloth. A piece of moistened cotton wool was placed in the bottom of each container to maintain the humidity. Then, these containers were kept in an incubator set at $25 \pm 2{ }^{\circ} \mathrm{C}, 60 \pm$ $10 \% \mathrm{RH}$ with a photoperiod of $16: 8$ hours (L: D) and were monitored daily until the adults appeared. After mating, the deposited eggs were kept until hatching. A cohort of 30 eggs was used for constructing life table. After emergence of first instars nymphs, they were provided with moistened cotton and left in the container. After molting, they were moved to individual Petri dishes $(90 \mathrm{~mm})$ covered with moistened cotton wool and were provided with the last larval instar of G. mellonella. The nymphs were checked daily until they reached the adult stage. The emerged adults were kept in pairs of one male and one female, and their mortality and the oviposition rate of female were recorded daily. In addition, life table parameters including the net reproductive rate $\left(R_{0}\right)$, intrinsic rate of increase $(r)$, finite rate of increase $(\lambda)$, doubling time $(D T)$ and mean generation time $(T)$ were determined.

\section{Biochemical analysis}

24- 48 and 72 hours after treatment with the sublethal concentration, i.e. the $\mathrm{LC}_{30}$ of $B$. bassiana, the surviving nymphs were used for the enzymes activity determination according to the following methods based on the previous work (18).

\section{Sample pre paration}

Each A. spinidens nymph was homogenized in $250 \mu \mathrm{l}$ of $0.2 \mathrm{M}$ phosphate buffer ( $\mathrm{pH} 7.0$ ) containing $0.05 \%$ triton $\mathrm{X}-100$ using a plastic pestle. Next, the homogenate was centrifuged at $12000 \mathrm{~g}$ for $10 \mathrm{~min}$ at $4^{\circ} \mathrm{C}$. The supernatant was used as an enzyme solution for assessing the esterase, glutathione S-transferase and AChE activity. For determination of head AChE activity, each head of A. spinidens nymph was homogenized in $30 \mu 1$ of $0.2 \mathrm{M}$ phosphate buffer $(\mathrm{pH} 7.0)$ containing $0.05 \%$ triton X-100 using a plastic pestle. The homogenate was centrifuged at $12000 \mathrm{~g}$ for 10 $\min$ at $4^{\circ} \mathrm{C}$.

\section{Esterase activity}

The esterase activity was measured according to van Asperen's method (19). The substrates were $\alpha$-NA and $\beta$-NA. $12.5 \mu 1$ of supernatant was added to a microplate containing $112.5 \mu \mathrm{l}$
GHOLAMZADEH-CHITGAR M., et al. $0.2 \mathrm{M}, \mathrm{pH} 7.0$, phosphate buffer per well. The addition of $50 \mu \mathrm{l}$ substrate per well $(0.65 \mathrm{mM}$ in buffer) initiated a reaction. After incubation for exactly $15 \mathrm{~min}$ at room temperature, $50 \mu \mathrm{l}$ of fast blue RR salt was added and the microplate left in the dark for $30 \mathrm{~min}$. Absorbance at $450 \mathrm{~nm}\left(\mathrm{OD}_{450}\right)$ was then measured continuously for $10 \mathrm{~min}$ with a microplate reader (Awareness Stat Fax ${ }^{\circledR}$ 3200).

\section{Glutathione S-transferase (GST) activity}

GST activity was determined using 1-chloro-2, 4-dinitrobenzene (CDNB) and reduced GSH as substrates with slight modifications according to Habig et al. (20). $15 \mu \mathrm{l}$ of supernatant was added to $70 \mu \mathrm{l} 0.2 \mathrm{M}, \mathrm{pH} 7.0$, phosphate buffer, $100 \mu \mathrm{l}$ CDNB and $100 \mu \mathrm{l}$ GSH in buffer. The non-enzymatic reaction of CDNB with GSH measured without supernatant served as control. The change in absorbance was measured continuously for $10 \mathrm{~min}$ at 340 $\mathrm{nm}$.

\section{Ace tylcholineste rase (AChE) activity}

$\mathrm{AChE}$ activity was measured according to the methods of Ellman et al. (21). Fifty microliters of the enzyme source was added to each well of microplate containing $140 \mu \mathrm{l}$ of $0.2 \mathrm{M}$ phosphate buffer ( $\mathrm{pH} 7.0$ ) and $20 \mu \mathrm{DTNB}$ solution. Then $40 \mu \mathrm{l}$ of ATC was added to each well. Optical density was measured continuously for $10 \mathrm{~min}$ at $415 \mathrm{~nm}$.

\section{Data analysis}

The $\mathrm{LC}_{30}$ value and $95 \%$ confidence intervals were calculated from probit regressions using the POLO-PC computer program (22). Life table parameters were determined according to Chi (23). Difference between the treatments was determined by $t$-test (24).

\section{Protein assay}

Total protein was determined according to Bradford method (25) with bovine serum albumin as standard.

\section{RESULTS}

Log concentration probit-mortality of $A$. spinidens to $B$. bassiana is shown in Figure 1. The $\mathrm{LC}_{30}$ value was found at concentration of $3 \times 10^{5}$ conidia $\mathrm{ml}^{-1}$ for fifth-instars nymphs of A. spinidens. Sublethal effects of B. bassiana on pre-oviposition period, fecundity, percent egg hatchability and longevity of A. spinidens are presented in Table 1. There was not significantly difference between treated insects and control in pre-oviposition period $(\mathrm{T}=$ $0.21, \mathrm{df}=19, p=0.836)$, fecundity $(\mathrm{T}=0.78$, $\mathrm{df}=26, \quad p=0.442)$, percent egg hatchability $(\mathrm{T}=0.76, \mathrm{df}=19, \quad p=0.456)$, female longevity $(\mathrm{T}=0.52, \mathrm{df}=26, p=0.60)$ and male longevity 
$(\mathrm{T}=0.36, \mathrm{df}=26, p=0.72)$. Sublethal effects of $B$. bassiana on life table parameters of $A$. spinidens are shown in Table 2. The $r$ value was not significantly affected in offspring of the treated predator $(\mathrm{T}=0.38, \mathrm{df}=58, p=0.704)$. There were not significant differences between $R_{0}$ values for $B$. bassiana in comparison with the control $(\mathrm{T}=0.57, \mathrm{df}=58, p=0.573)$. The mean generation time $(\mathrm{T}=0.36, \mathrm{df}=58, p=0.92)$, the doubling time $(\mathrm{T}=0.80, \mathrm{df}=58, p=0.427)$,
GHOLAMZADEH-CHITGAR M., et al. and the finite rate of increase $(\mathrm{T}=0.38, \mathrm{df}=58$, $p=0.703$ ) did not vary significantly between treatments. The course of the age-specific survival rate $\left(l_{x}\right)$ and the age-specific number of progeny per day $\left(m_{x}\right)$ of $A$. spinidens for treated and untreated females are presented in Figure 2. The last female remained alive on $77^{\text {th }}$ day was seen in control, however in $B$. bassiana treatment the death of last female occurred approximately at the age of 71 days.

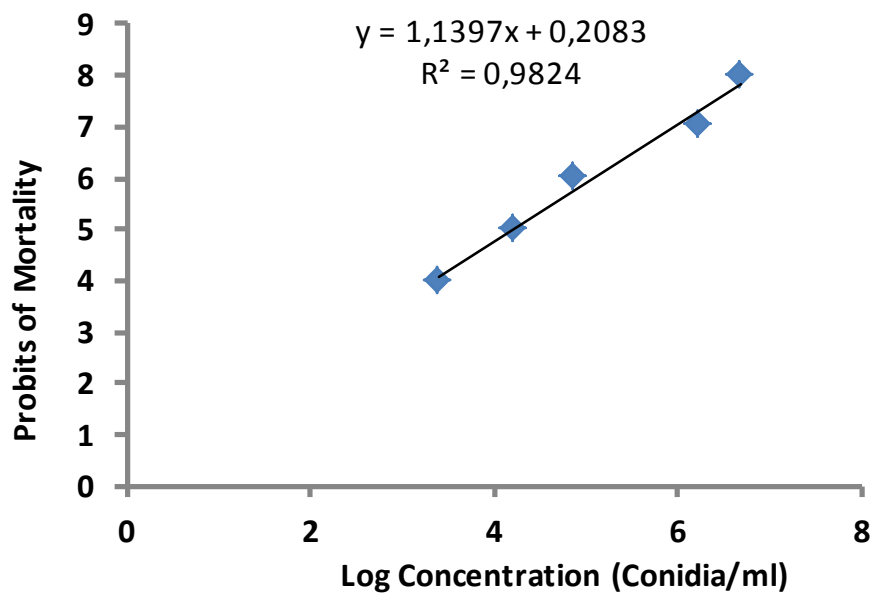

Figure 1. Log concentration probit-mortality of fifth-instars nymphs of Andrallus spinidens to Beauveria bassiana

Table 1. Effects of Beauveria bassiana on biological parameters of Andrallus spinidens

\begin{tabular}{cccccc}
\hline Treatments & Fecundity & Egg hatch\% & $\begin{array}{c}\text { pre-oviposition period } \\
\text { (day) }\end{array}$ & \multicolumn{2}{c}{ Longevity(day) } \\
\cline { 3 - 5 } & & & Female & Male \\
\hline Control & $108.2 \pm 21.3 \mathrm{a}$ & $98.4 \pm 18.2 \mathrm{a}$ & $8.36 \pm 0.9 \mathrm{a}$ & $30.92 \pm 4.4 \mathrm{a}$ & $17.83 \pm 3.1 \mathrm{a}$ \\
B. bassiana & $86 \pm 18.7 \mathrm{a}$ & $95 \pm 15.3 \mathrm{a}$ & $8.6 \pm 0.5 \mathrm{a}$ & $27.78 \pm 4.1 \mathrm{a}$ & $16.27 \pm 2.9 \mathrm{a}$ \\
\hline
\end{tabular}

Means \pm SE in the columns with the same letter are not significantly different $(p \leq 0.05)$

Table 2. Effects of Beauveria bassiana on the life table parameters of Andrallus spinidens

\begin{tabular}{cccccc}
\hline Treatments & $r\left(\right.$ day $\left.^{-1}\right)$ & $\lambda\left(\right.$ day $\left.^{-1}\right)$ & $D T$ (day) & $T$ (day) & $\begin{array}{c}R_{0}(\text { females } \\
\text { offspring/female) }\end{array}$ \\
\hline Control & $0.085 \pm 0.006 \mathrm{a}$ & $1.088 \pm 0.006 \mathrm{a}$ & $8.15 \pm 0.50 \mathrm{a}$ & $46.51 \pm 1.01 \mathrm{a}$ & $50.53 \pm 13.99 \mathrm{a}$ \\
B. bassiana & $0.081 \pm 0.006 \mathrm{a}$ & $1.085 \pm 0.007 \mathrm{a}$ & $8.55 \pm 0.57 \mathrm{a}$ & $45.76 \pm 0.93 \mathrm{a}$ & $40.2 \pm 11.7 \mathrm{a}$ \\
\hline
\end{tabular}

Means \pm SE in the columns with the same letter are not significantly different $(p \leq 0.05)$

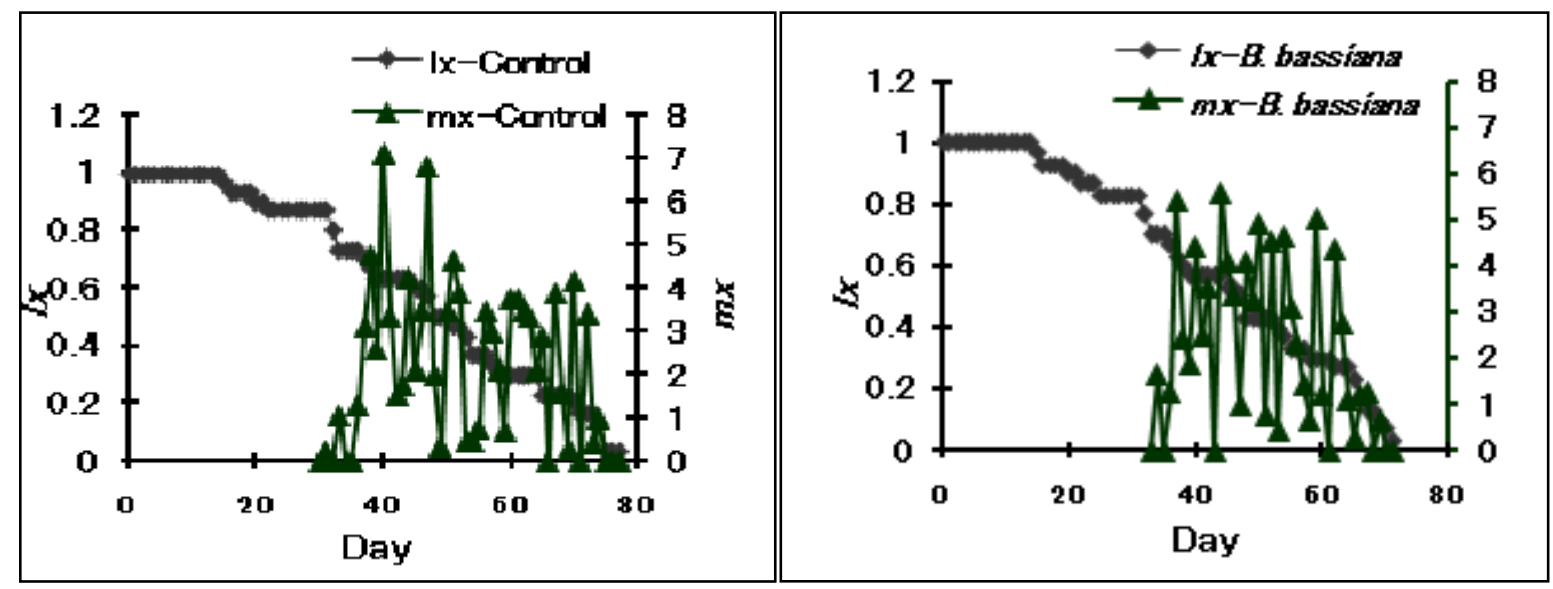

B

A

Figure 2. Effect of Beauveria bassiana (B) in comparison with the control(A) on age specific survival rate $\left(l_{x}\right)$ and age specific fecundity $\left(m_{x}\right)$ of Andrallus spinidens 
Effect of $B$. bassiana on the esterase activity in A. spinidens is shown in Table 3. Using $\alpha$ naphtil as substrate, esterase activity had not significantly difference between $B$. bassiana and control in $24 \mathrm{~h}(\mathrm{~T}=-2.10, \mathrm{df}=4, p=0.103)$, $48 \mathrm{~h}(\mathrm{~T}=-3.6, \mathrm{df}=4, p=0.022)$ and $72 \mathrm{~h}$ $(\mathrm{T}=0.95, \mathrm{df}=4, p=0.396)$ after treatment. But the enzyme activity showed significant changes between treated and untreated bugs when $\beta$ - naphtil was used as substrate. The results showed significantly difference in $24 \mathrm{~h}$ $(\mathrm{T}=5.34, \mathrm{df}=4, p=0.0059), 48 \mathrm{~h}(\mathrm{~T}=-9.93$, $\mathrm{df}=4, \quad p=0.006)$ and $72 \mathrm{~h}(\mathrm{~T}=4.82, \quad \mathrm{df}=4$, $p=0.0085$ ) after treatment between treated insects and control. Effect of $B$. bassiana on the AChE activity in A. spinidens is shown in
GHOLAMZADEH-CHITGAR M., et al.

Table 4. Head AChE activity in $24 \mathrm{~h}(\mathrm{~T}=0.27$, $\mathrm{df}=4, p=0.813), 48 \mathrm{~h} \quad(\mathrm{~T}=-1.47, \mathrm{df}=4, p$ $=0.279)$ and $72 \mathrm{~h}(\mathrm{~T}=-1.75, \mathrm{df}=4, p=0.222)$ after treatment was not significant. Also, body AChE activity in $24 \mathrm{~h}(\mathrm{~T}=-19, \mathrm{df}=4, p=0.028)$, $48 \mathrm{~h}(\mathrm{~T}=-5.62, \mathrm{df}=4, p=0.03)$ and $72 \mathrm{~h}(\mathrm{~T}=$ 2.7, $\mathrm{df}=4, p=0.114$ ) after treatment had not significant difference in treated $A$. spinidens in comparison with the control. Effect of $B$. bassiana on the GST activity in A. spinidens is shown in Table 5. GST activity was affected by $B$. bassiana in $24 \mathrm{~h}(\mathrm{~T}=6.48, \mathrm{df}=4$, $p=0.0029), 48 \mathrm{~h}(\mathrm{~T}=-11.44, \mathrm{df}=4, p=0.0003)$ and $72 \mathrm{~h}(\mathrm{~T}=-1.15, \mathrm{df}=4, p=0.0031)$ after treatment.

Table 3. Effects of Beauveria bassiana on the esterase activity of Andrallus spinidens ( $\mathrm{mmol} \mathrm{min}^{-1} \mathrm{mg}$ protein $\left.^{-1}\right)$

\begin{tabular}{cccc}
\hline & \multicolumn{3}{c}{ Esterase activity $\left(\mathrm{nmol} \min ^{-1} \mathrm{mg}\right.$ protein $\left.^{-1}\right)$} \\
\cline { 2 - 4 }$\alpha$-naphtil as substrate & Time $(\mathrm{h})$ & Control & B. bassiana \\
& 24 & $1082.14 \pm 0.002$ & $2118.77 \pm 0.195$ \\
& 48 & $927.08 \pm 0.009$ & $1345.87 \pm 0.55$ \\
\hline$\beta$-naphtil as substrate & 72 & $2729.15 \pm 0.016$ & $2253.78 \pm 0.152$ \\
& 24 & $350.19 \pm 0.011$ & $339.33 \pm 0.003^{*}$ \\
& 48 & $149.12 \pm 0.007$ & $404.37 \pm 0.006^{*}$ \\
& 72 & $418.6 \pm 0.01$ & $290.49 \pm 0.01^{*}$ \\
\hline
\end{tabular}

Means \pm SE in rows followed by $(*)$ differ significantly $(p \leq 0.05)$

Table 4. Effects of Beauveria bassiana on the AchE activity of Andrallus spinidens (nmol min ${ }^{-1} \mathrm{mg}$ protein $^{-1}$ )

\begin{tabular}{cccc}
\hline & \multicolumn{3}{c}{ AchE activity $\left(\mathrm{nmol} \mathrm{min}^{-1} \mathrm{mg}\right.$ protein $\left.^{-1}\right)$} \\
\cline { 2 - 4 } & Time $(\mathrm{h})$ & Control & B. bassiana \\
\hline Head & 24 & $78.22 \pm 0.005 \mathrm{a}$ & $55.94 \pm 0.01 \mathrm{a}$ \\
& 48 & $22.12 \pm 0.002 \mathrm{a}$ & $56.16 \pm 0.01 \mathrm{a}$ \\
& 72 & $22.38 \pm 0.0005 \mathrm{a}$ & $61.5 \pm 0.01 \mathrm{a}$ \\
\hline Body & 24 & $30.79 \pm 0.002 \mathrm{a}$ & $58.1 \pm 0.0015 \mathrm{a}$ \\
& 48 & $23.12 \pm 0.006 \mathrm{a}$ & $49 \pm 0.0025 \mathrm{a}$ \\
& 72 & $72.57 \pm 0.0008 \mathrm{a}$ & $35 \pm 0.0005 \mathrm{a}$ \\
\hline
\end{tabular}

Means \pm SE in the rows with the same letter are not significantly different $(p \leq 0.05)$

Table 5. Effects of Beauveria bassiana on the GST activity of Andrallus spinidens ( $\mu \mathrm{mol} \mathrm{min}^{-1} \mathrm{mg}$ protein $\left.^{-1}\right)$

\begin{tabular}{cccc}
\hline Treatment & \multicolumn{3}{c}{ GST activity $\left(\mu \mathrm{mol} \mathrm{min}^{-1} \mathrm{mg} \mathrm{protein}^{-1}\right)$} \\
\cline { 2 - 4 } & $24 \mathrm{~h}$ & $48 \mathrm{~h}$ & $72 \mathrm{~h}$ \\
\hline Control & $10.95 \pm 0.009$ & $8.10 \pm 0.011$ & $9.731 \pm 0.035$ \\
B. bassiana & $10.60 \pm 0.02^{*}$ & $11.24 \pm 0.014^{*}$ & $10.11 \pm 0.031^{*}$ \\
\hline
\end{tabular}

Note: Means \pm SE in columns followed by $(*)$ differ significantly $(p \leq 0.05)$

\section{DISCUSSION}

Problems with synthetic chemical insecticides have given rise to a sense of urgency in the development of biological control agents as supplements or alternatives to these chemicals.
B. bassiana is the main entomopathogenic fungus in Iran, which has been used against many insect pests including rice lepidopter pests (10). Therefore, it is necessary to investigate its effect on non target insects prior 
to their release. In theory, if the predatory insect species are susceptible to $B$. bassiana after conidia are directly applied, or the insect is indirectly infected via feeding on contaminated surfaces, the potential of the fungal pathogen for integrated pest management would be compromised. However, if their effects on natural enemies are low compared with currently used synthetic insecticides, entomopathogenic fungi could be a compatible component with natural enemies in an IPM programme (26).

There are a lot of works about the effect of $B$. bassiana on non target insects $(1,27,28)$ but, only a few studies have reported the sideeffects of the fungus on life table parameters (13).

The results of the present study clearly demonstrated that the reproduction, longevity and the percentage of hatched eggs of $A$. spinidens was not affected significantly after exposure to $B$. bassiana at a concentration of $3 \times 10^{5}$ conidia $\mathrm{ml}^{-1}$. In agreement with our findings, fecundity, egg viability and longevity of Prynocaria congener Billberg (Coleoptera: Coccinellidae) females did not differ significantly by $B$. bassiana treatment at a concentration of $10^{4}$ conidia $\mathrm{ml}^{-1}$ (13). Strain $\mathrm{Bb} 21$ of $B$. bassiana at concentration of $5 \times 10^{8}$ conidia $\mathrm{ml}^{-1}$ had not important effect on egg production of Chrysoperla carnea (Chrysopidae) and Harmonia axyridis (Col: Coccinellidae) (29). While, some authors did not find a significant change in the fecundity and or longevity in the exposed insect by pathogens, others reported the opposite result. For example, adult longevity of Orius sauteri (Hemiptera: Anthocoridae) decreased by 9$13 \%$ when feeding on Frankliniella occidentalis Pergande (Tysanoptera: Thripidae) larvae contaminated by $B$. bassiana at concentrations of $10^{4}$ and $10^{8}$ conidia $\mathrm{ml}^{-1}$ compared with those fed $F$. occidentalis larvae not treated with B. bassiana (9Gao et al. 2012). Also, B. basssiana at concentrations of $10^{5}, 10^{7}$ and $10^{9}$ conidia $\mathrm{ml}^{-1}$ reduced $H$. axyridis egg production dramatically and at a concentration of $10^{9}$ conidia $\mathrm{ml}^{-1}$ reduced the fecundity of Adalia bipunctata (Col.: Coccinellidae) to zero (29). Hajek and St. Leger (30) reported that entomopathogenic fungi affected the host insect through a combination of events including mechanical damage by hyphal growth, nutrient depletion, and the production of toxins. Any of these processes at a sublethal level could negatively affect the reproductive system of the host. A fungal infection initiated at this time and the resulting physiological
GHOLAMZADEH-CHITGAR M., et al. stress could interfere with egg development (31).

In the current study, the life table parameters of A. spinidens were not significantly affected by $B$. bassiana. These results are in agreement with $B$. bassiana treatment $\left(10^{4}\right.$ and $10^{8}$ conidia $\mathrm{ml}^{-1}$ ) in $P$. congener where $r, T, R_{0}$ and $\lambda$ did not differ significantly (13). Also, life table parameters of Serangium japonicum Chapin (Col.: Coccinellidae) were not affected by $V$. lecanii at concentrations of $10^{4}, 10^{5}, 10^{6}$, $10^{7}$ and $10^{8}$ conidia $\mathrm{ml}^{-1}$ (32). Xu et al. (33) showed no significant effects of $V$. lecanii $\left(10^{7}\right.$ conidia $\mathrm{ml}^{-1}$ ) on life table parameters of Axinoscymnus cardilobus (Col.: Coccinellidae).

Xenobiotics are largely detoxified by various enzymes. Glutathione S-transferases and nonspecific esterases are most commonly involved in this process in insects (15).

Esterase activity (using $\alpha$ and $\beta$ - naphtil) in the untreated bugs increased in the $3^{\text {th }}$ day after treatment. It is reported that general esterase activity increases with aging, and newly emerged insects have a much lower level of general esterase activity than mature insects (34). Using $\beta$ - naphtil as substerate, enzyme activity was increased significantly $48 \mathrm{~h}$ after treatment by $B$. bassiana. A 2-3-fold increase in esterase activity was observed in the hemolymph of $G$. mellonella two days after infection by $B$. bassiana at concentration of $10^{7}$ conidia $1^{-1}(15)$. Similar results were found on esterase activity in treated G. mellonella by Paecilomyces fumosoroseus Wize and Metarhizium anisopliae (35Serebrov et al. 2001). Increased activity of detoxification enzymes in mycoses and other infections represents the insect response to body intoxication with metabolites of the pathogen or with products of host tissue degradation (15). Acetylcholinesterase (AChE) is a key enzyme that terminates nerve impulses by catalyzing the hydrolysis of the neurotransmitter acetylcholine in the nervous system. In this study, B. bassiana had not significant effect on AChE activity in both head and body of $A$. spinidens. GST activity was affected by $B$. bassiana at concentration of $3 \times 10^{5}$ conidia $\mathrm{ml}^{-1}$. The enzyme activity in $A$. spinidens was increased $48 \mathrm{~h}$ after treatment by $B$. bassiana. Fungal infection of insect increases glutathione $S$-transferase activity (15). Similar results were reported by Fan et al. (36) in the treated larvae of Dendrolimus tabulaeformis Tsai et Liu (Lep.: Lasiocampidae) by B. brongniartii Saccardo Petch at concentrations of $6 \times 10^{6}$ and $6 \times 10^{7}$ 
conidia $\mathrm{ml}^{-1}$. Induction of GST activity is an indication of a detoxification process (37).

According to the present study, B. bassiana at concentration of $3 \times 10^{5}$ conidia $\mathrm{ml}^{-1}$ had not detrimental effects on life table parameters and enzymes activity of $A$. spinidens. It can be concluded that $B$. bassiana is compatible with the predatory bug at sublethal concentration $\left(\mathrm{LC}_{30}\right)$.

\section{ACKNOWLEDGMENTS}

The authors express their gratitude to the Research Council of the University of Guilan and the Ministry of Science, Research and Technology for financial support during the course of this project.

\section{REFERENCES}

1. Thungrabeab, M. and Tongma, S., Effect of entomopathogenic fungi, Beauveria bassiana (Balsam) and Metarhizium anisopliae (Metsch) on non target insects. Kmitl Sci Tech J, 7: 8-12, 2007.

2. Manley, G.V., Biology and life history of the rice field predator Andrallus spinidens F. (Heteroptera: Pentatomidae). Entomol News, 93: 19-24, 1982.

3. Mohaghegh, J., Najafi, I., Predation capacity of Andrallus spinidens (F.) (Het.: Pentatomidae) on Naranga aenescens Moore (Lep.: Noctuidae) under semi-field and field conditions. Appl Entomol Phytopathol, 71: 57-68, 2003.

4. Behera, K.S. and Prakash, A., Indian Insect Predators on insect pests of rice. India insect predators in biological control. $p$. 275-296, 2004.

5. Thomas, D.B., Taxonomic synopsis of the Old World asopine genera (Heteroptera: Pentatomidae). Insecta Mundi, 8: 145-212, 1994.

6. Nageswara Rao, V., Andrallus (Audinetia) spinidens Fabr., as Predator on Rice Pests. Oryza. 2: 179-181, 1965.

7. Jacobson, R.J., Chandler, D., Fenlon, J. and Russell, K.M., Compatibility of Beauveria bassiana (Balsamo) Vuillemin With Amblyseius cucumeris Oudemans (Acarina: Phytoseiidae) to Control Frankliniella occidentalis Pergande (Thysanoptera: Thripidae) on Cucumber Plants. Biocontrol Sci Techn, 11: 391-400, 2001.

8. Down, R.E., Cuthbertson, A.G.S., Mathers, J.J. and Walters, K.F.A., Dissemination of the Entomopathogenic Fungi, Lecanicillium longisporum and L. muscarium, by the Predatory Bug, Orius laevigatus, to Provide Concurrent Control of Myzus persicae, Frankliniella occidentalis and Bemisia tabaci. Biolog Control, 50: 172-178, 2009.
GHOLAMZADEH-CHITGAR M., et al.

9. Gao, Y., Reitz, S.R., Wang, J., TamezGuerra, P., Wang, E., Xu, X. and Lei, Z., Potential use of the fungus Beauveria bassiana against the western flower thrips Frankliniella occidentalis without reducing the effectiveness of its natural predator Orius sauteri (Hemiptera: Anthocoridae). Biocontrol Sci Techn, 22(7): 803-812, 2012.

10. MajidiShilsar, F., Padash-Dehkaee, F. and Nahvi, M., Biological control of Chilo suppressalis by Beauveria bassiana fungus after rice harvesting in the field conditions. J Plant Prot, 25(2): 186-193, 2011.

11. Traugott, M., Weissteiner, S. and Strasser, H., Effects of the Entomopathogenic Fungus Beauveria brongniartii on the NonTarget Predator Poecilus versicolor (Coleoptera: Carabidae). Biol Control, 33: 107-112, 2005.

12. Labbe', R.M., Gillespie, D.R., Cloutier and C., Brodeur, J., Compatibility of an Entomopathogenic fungus with a predator and a parasitoid in the biological control of greenhouse whitefly. Biocontrol Sci Technol, 19: 429-446, 2009.

13. Huang, Z., Ali, S., Ren, SH., Wu, J. and Zhang, Y., Influence of the entomopathogenic fungus Beauveria bassiana on Prynocaria congener (Billberg) (Coleoptera: Coccinellidae) under laboratory conditions. Pakistan J Zool, 44(1): 209-216, 2012.

14. Stark, J.D., Sugayama, R.L. and Kovaleski, A., Why demographic and modeling approaches should be adopted for estimating the effects of pesticides on biocontrol agents. BioControl, 52 (3): 365374, 2007.

15. Serebrov, V.V., Gerber, O.N., Malyarchuk, A.A., Martemyanov, V.V., Alekseev, A.A., Glupov, V.V., Effect of Entomopathogenic Fungi on Detoxification Enzyme Activity in Greater Wax Moth Galleria mellonella L. (Lepidoptera: Pyralidae) and Role of Detoxification Enzymes in Development of Insect Resistance to Entomopathogenic Fungi. Biol Bull, 33 (6): 581-586, 2006.

16. Sak, O., Uçkan, F. and Ergin, E., Effects of Cypermethrin on Total Body Weight, Glycogen, Protein, and Lipid Contents of Pimpla turionellae (L.) (Hymenoptera : Ichneumonidae). Belg J Zool, 136 (1): 5358, 2006.

17. Kammenga, J. and Laskowski, R., Demography in Ecotoxicology. John Wiley and Sons. 297 pp, 2000.

18. Gholamzadeh-Chitgar, M., Hajizadeh, J., Ghadamyari, M., Karimi-Malati, A. and Hoda, H., Effects of sublethal concentration 
of diazinon, fenitrothion and chlorpyrifos on demographic and some biochemical parameters of predatory bug, Andrallus spinidens Fabricius (Hemiptera: Pentatomidae) in laboratory conditions. Int J Pest Manag, 61: 3, 204-211, 2015.

19. Van Asperen, K., A study of housefly esterases by means of a sensitive colorimetric method. J Insect Physiol, 8: 401-416, 1962.

20. Habig, W.H., Pabst, M.J. and Jakoby, W.B., Glutathion s-transferase, the first step in mercapturic acid formation. $J$ Biol Chem, 249:7130-7139, 1974.

21. Ellman, G.L., Courtney, K.D., Andres, V.Jr. and Featherstone, R.M., A new and rapid colorimetric determination of acetylcholinesterase activity. Biochem Pharmacol, 7: 88-95, 1961.

22. LeOra Software., POLO-PC: a user guide to probit or logit 786 analysis. Berkeley (CA): LeOra software, 1987.

23. Chi, H., Consume-MSChart: a computer program for the age-stage, two-sex life table analysis. Available from: http:// 140.120.197.173/Ecology, 2009.

24. SAS Institute., SAS/STAT user's guide. SAS Institute Inc., Cary, NC Inc., 2002.

25. Bradford, M., A rapid and sensitive method for quantitation of microgram quantities of protein utilizing the principle of protein-dye binding. Analyt Biochem, 72: 248- 254, 1976.

26. Strasser, H., Vey, A., Butt, T.M., Are There Any Risks in Using Entomopathogenic Fungi for Pest Control, With Particular Reference to the Bioactive Metabolites of Metarhizium, Tolypocladium and Beauveria species? Biocontrol Sci Techn, 10: 717-735, 2000.

27. Smith, S.F. and Krischik, V.A., Effects of biorational pesticides on four Coccinellid species (Coleoptera: Coccinellidae) having potential as biological control Agents in Interiorscapes. Entomol Soc Am, 93(3): 732-736, 2001.

28. Roy, H., Brown, P., Rothery, P., Ware, R. and Marjerus, M., Interactions between the fungal pathogen Beauveria bassiana and three species of coccinellid: Harmonia axyridis, Coccinella septempunctata and Adalia bipunctata. BioControl, 53: 265276, 2008.
GHOLAMZADEH-CHITGAR M., et al.

29. Zhu, H., Luo, X.M., Song, J.X., Fan, M.Z. and Li, Z.Z., Effects of Beauveria bassiana on Myzus persicae and its two predaceous natural enemies. Yingyong Shengtai Xuebao, 22(9): 2413-2418, 2011.

30. Hajek, A.E. and St Leger, R.J., Interactions between fungal pathogens and insect hosts. Ann Rev Entomol, 39: 293-322, 1994.

31. Mulock, S.B. and Chandler, L.D., Effect of Beauveria bassiana on the fecundity of western corn rootworm, Diabrotica virgifera virgifera (Coleoptera: Chrysomelidae). Biolog Control, 22: 16-21, 2001.

32. Fatiha, L., Huang, Z., Ren, S.X., Ali, S., Effect of Verticillium lecanii on biological characteristics and life table of Serangium japonicum (Coleoptera: Coccinellidae), a predator of whiteflies under laboratory conditions. Insect Sci, 15: 327-333, 2008.

33. Xu, D., Ali, S., Huang, Z., Zhou, F., Afzal, M. and Bashir, M., Influence of the entomopathogenic fungus, Verticillium lecanii on the whitefly predator, Axinoscymnus cardilobus (Coleoptera: Coccinellidae) under laboratory conditions. Pakistan J Zool, 41(4): 289-295, 2009.

34. Pruett, J.H., Kammlah, D.M. and Guerrero, F.D., Variation in general esterase activity within a population of Haematobia irritans (Diptera: Muscidae). J Econ Entomol. 94 (3): 714-718, 2001.

35. Serebrov, V.V., Alekseev, A.A. and Glupov, V.V., Changes in the activity and pattern of hemolymph esterases in the larvae of wax moth Galleria mellonella $\mathrm{L}$. (Lepidoptera, Pyralidae) during mycosis. Izv Akad Nauk Ser Biol, 5: 588-592, 2001.

36. Fan, J., Xie, Y., Xue, J. and Liu, R., The Effect of Beauveria brongniartii and its secondary metabolites on the detoxification enzymes of the pne caterpillar, Dendrolimus tabulaeformis. J Insect Sci, vailable: http://www.insectscience.org/, 13: 44, 2013.

37. Jemec, A., Drobne, D., Tišler, T., Trebše, P., Roš, M. and Sepčić, K., The applicability of acetylcholinesterase and glutathione S-transferase in Daphnia magna toxicity test. Comp. Biochem. Physiol, Part C, 144: 303-309, 2007. 